\title{
COMBATE EPISTEMOLÓGICO, COMBATE DE PODER: DEL TETELESMÉNON AL DÓKOS
}

\author{
EPISTEMOLOGICAL STRUGGLE, POWER STRUGGLE: FROM \\ TETELESMÉNON TO DÓKOS
}

\author{
Jonathan Lavilla de Lera ${ }^{1}$ \\ Universidad de Barcelona y Eidos HP\&M (España)
}

Recibido: 29-01-2013

Aceptado: 11-10-2013

\begin{abstract}
Resumen: El artículo se remonta a la Grecia Arcaica para analizar algunos de los cambios sociales y epistemológicos más significativos que se produjeron y que resultaron decisivos para el posterior desarrollo de la cultura. Para ello, hemos seleccionado cuatro momentos de aquel proceso: 1) el paso de la oralidad a la escritura; 2) la fijación textual de la tradición homérica; 3) la crítica a Homero de Jenófanes de Colofón; 4) la apología de Teágenes de Regio. A través de este recorrido constataremos que las disputas epistemológicas surgidas iban de la mano de determinados conflictos materiales. La lucha epistemológica era también una lucha de poder.
\end{abstract}

Palabras-clave: epistemología, oralidad, alfabetización, alegorismo, dókos.

\begin{abstract}
The article, which dates back to Archaic Greece, gives an account of how the social and epistemological changes that took place at around that time were vital for the development of culture. Four significant stages of that process will be described to illustrate this: 1) the transition from spoken to written culture; 2) the textual establishment of the Homeric tradition; 3) Xenophanes of Colophon's criticism of Homer; 4) Theagenes of Rhegium's eulogy. This trip will reveal that the epistemological disputes went hand in hand with certain material conflicts. The epistemological quest was already a struggle for power.
\end{abstract} Key-words: epistemology, orality, literacy, allegorism, dókos.

[1] (jlavilla@ub.edu) Jonathan Lavilla de Lera es licenciado en Filosofía por la Universidad de Barcelona (UB). En la actualidad es investigador en formación del Departamento de Historia de la Filosofía, Estética y Filosofía de la Cultura (UB), gracias a una beca predoctoral del Gobierno de Navarra. Escribe su tesis doctoral sobre el Fedro de Platón y por segundo año imparte la asignatura de Antropología Filosófica del Grado en Filosofía (UB). 


\section{Introducción}

No existe el milagro griego. La Grecia clásica y su debate intelectual y político responden a un proceso histórico y a una realidad material precisa. Monarquía, aristocracia, oligarquía, tiranía, democracia son algunas de las diferentes caras que en lo político adopta un desarrollo que hunde sus raíces en unas tierras menos evidentes. De la misma forma, los debates epistemológicos de la pólis responden al proceso en el que el hombre trata de comprender y dominar su mundo.

Por ello, aunque cabe reconocer que entre la Grecia del período arcaico y del clásico se aprecia una brecha profunda, entre ellas se da una mediación real. Las reflexiones que nos han llegado de los autores del siglo VI y comienzos del $\mathrm{V}$ a. C. nos resultan harto más oscuras que las de las figuras de la segunda mitad del siglo V y del IV. Los fragmentos de los presocráticos se nos manifiestan crípticos; apenas unos decenios los separan de los textos clásicos y, sin embargo, su lenguaje resulta mucho más extraño. Las argumentaciones de Gorgias o Protágoras no nos plantean la dificultad comprensiva de Empédocles. Por tanto, sin negar el hiato que se abre entre ambos mundos, la reflexión que en lo sucesivo desplegaremos debería mostrar los profundos vínculos entre ellos.

Mucho se ha escrito sobre el paso de la Grecia arcaica a la clásica. J. P. Vernant $^{2}$, M. Detienne ${ }^{3}$, E. R. Doods ${ }^{4}$, E. A. Havelock ${ }^{5}$, entre otros ${ }^{6}$, han dado algunas de las explicaciones más esclarecedoras. Nosotros combinaremos las diferentes argumentaciones tratando de privilegiar aquellas que resulten más pertinentes para nuestro propósito, el cual consistirá en mostrar que, a partir del siglo VI a. C., comienza a destacarse una fuerte lucha social e ideológica que propiciará la creación de novedosas y diferentes propuestas epistemológicas. En ese sentido, articularemos nuestra reflexión en cuatro momentos; en el primero, esbozaremos los rasgos básicos de la sociedad griega arcaica y nos referiremos a algunas de las novedades que comporta la introducción del alfabeto; en el segundo, nuestra atención se dirigirá a la fijación del texto homérico; en tercer lugar, daremos noticia de Jenófanes de Colofón y del corte epistemológico que le acompaña; por último, aludiremos a Teágenes de Regio, constatando que el marco cognoscitivo ha cambiado.

[2] Vernant, J.-P., Los orígenes del pensamiento griego, trad. de M. Ayerra, Barcelona, Paidós, 1992.

[3] Detienne, M., Los maestros de verdad en la Grecia arcaica, trad. de J. J. Herrera, Madrid, Taurus, 1986.

[4] Dodds, E. R., Los griegos y lo irracional, traducción de M. Araujo, Madrid, Alianza, 1980.

[5] Havelock, E. A., La musa aprende a escribir, trad. de L. Bredlow, Barcelona, Paidós, 1996; Havelock, E. A., Prefacio a Platón, trad. de R. Buenaventura, Madrid, Antonio Machado Libros, 2002.

[6] Dada la sobreabundancia de bibliografía secundaria acerca del tema tratado, hemos preferido ayudarnos de unas pocas obras esenciales y acudir, en cambio, a las fuentes primarias para elaborar un discurso relativamente autónomo.

THÉMATA. Revista de Filosofía, Nº49 enero-junio (2014) pp.: 159-184

doi: 10.12795/themata.2014.i49.09 


\section{La Grecia pre-gramática}

En primer lugar, nos apoyaremos en los textos de E. A. Havelock para tratar de plasmar los rasgos esenciales de la pólis arcaica. Ésta nace en torno al siglo VIII a. C. como estructura social y apenas conservamos indicios de sus albores. En cualquier caso, la ciudad-estado inaugura una época que deja atrás la era conocida como Edad Oscura, período en el que los pueblos griegos no disponían de la técnica de la escritura alfabética. De manera similar, en un inicio las póleis tampoco disponían de ésta, sino que fue introducida en Grecia hacia mediados de ese mismo siglo y, primeramente, su función era residual, secundaria ${ }^{7}$. Precisamente, Havelock analiza el paso de la pólis arcaica a la clásica en relación con la adopción de la técnica de la escritura y su desarrollo, cuya repercusión resultó decisiva.

Una sociedad no puede estructurarse como un simple conglomerado de individuos, sino que debe procurar que sus integrantes asimilen la "normalidad" de la misma, dotándolos de una legalidad, moralidad, imaginario e identidad comunes: cada sociedad ha de hacer de una pluralidad un todo. En una cultura gramática la educación y la política desempeñan algunas de las actividades más determinantes a este respecto. Sin ir más lejos, en nuestra época un aparato de leyes escritas y diferentes sistemas educativos se encargan de dotar de cohesión al grupo. Sin la ayuda de la letra, en cambio, esta labor resulta más compleja. En una cultura pre-gramática la tarea de delimitar las fronteras de lo permisible e imprimir a la sociedad una identidad común debe recaer en un determinado tipo de palabra hablada. En efecto, en Grecia existía un tipo de discurso privilegiado, encargado de instruir y regir a los hombres. M. Detienne analiza este fenómeno de forma lúcida ${ }^{8}$ : reyes, oráculos, adivinos y aedos ${ }^{9}$ detentarían el privilegio de ser los medios a través de los cuales se manifiesta la palabra de los dioses en la tierra. Son los maestros de verdad de aquella época, su mensaje viene de la esfera divina y jamás se pone en tela de juicio. Su palabra es realidad y crea realidad.

Los maestros de verdad, de hecho, no hacen sino manifestar la tradición, la memoria, lo que se considera que ha sido desde siempre y que ha de permanecer eternamente. Al constituir dones provenientes de la inspiración de las Musas y al revestirse, por tanto, con una legitimidad áurea, para los griegos la Verdad (Alétheia), la Tradición y la Memoria todavía no eran netamente divisibles:

[7] Suele decirse que su función era "monumental". Serviría para dejar inscripciones en algunos objetos como jarras o vasijas y en algunos monumentos mortuorios.

[8] Detienne, M., óp. cit.

[9] En el presente artículo nos limitaremos a rastrear la figura del aedo.

THÉMATA. Revista de Filosofía, Nº49 enero-junio (2014) pp.: 159-184

doi: 10.12795/themata.2014.i49.09 


\begin{abstract}
"la memoria divinizada de los griegos no responde en modo alguno a los mismos fines que la nuestra. No tiende, en absoluto, a reconstruir el pasado según una perspectiva temporal. La memoria sacralizada es, en primer lugar, un privilegio de determinados grupos de hombres constituidos en hermandades: (...) la memoria es una omnisciencia de carácter adivinatorio" ${ }^{10}$. A tal respecto, los textos homéricos son la mejor fuente arqueológica de la que disponemos, pues a pesar de ser documentos escritos, constituyen la fijación de la tradición que el aedo entonaba desde tiempos muy remotos. Los cantos homéricos debieron fijarse por escrito en el siglo VI, si bien, en tanto que tradición oral, se remontan, al menos, hasta el mismo siglo en el que aparece la ciudad-estado griega ${ }^{11}$.
\end{abstract}

Precisamente, Havelock defiende que la poesía (la palabra ritmada del aedo) constituía la columna vertebral de aquella sociedad ágrafa. La clave para que una sociedad permanezca consiste en la continuidad de su cultura, a saber, en la constante transmisión de una serie de saberes y valores que le procuren al grupo la supervivencia y una identidad. En ese sentido, las nuevas generaciones tienden a repetir las prácticas de sus mayores. Sin embargo, tal mecanismo no resulta en sí mismo suficiente y requiere una fuente de cohesión más sólida, a saber, de lo que Havelock describe como la oralidad. La cultura, las distintas técnicas, leyes consuetudinarias, creencias comunes y el lenguaje eran transmitidos de viva voz y gracias a una determinada forma lingüística, suministrando a la colectividad una serie de disposiciones de conducta. La poesía narraba acciones que, ritualizadas, debían ser reproducidas o rechazadas en función de las circunstancias. En el caso griego, los textos épicos nos dan buena muestra de dicho lenguaje $\mathrm{e}^{12}$. Su mensaje constituye la tradición, la propia memoria viva, social y colectiva que va transmitiéndose de generación en generación gracias a la especial capacidad mnemotécnica de la gente que vive en una cultura oral y de la inestimable labor de los aedos, garantes de la misma.

Si bien en el presente artículo no analizaremos las particularidades de dicho lenguaje, conviene señalar lo que sigue:

"la única tecnología verbal capaz de garantizar la conservación y la estabilidad de lo transmitido consistía en la palabra rítmica hábilmente organizada según modelos métricos y verbales lo suficientemente únicos para retener la forma. Tal es la génesis histórica, la fons et origo, la causa originaria del fenómeno que aún hoy denominamos "poesía»"13.

[10] Detienne, M., óp cit.

[11] En este punto las opiniones divergen bastante. Algunos, como Havelock, creen que los cantos homéricos provienen del Período Oscuro e incluso de la Época Micénica. Otros, en cambio, como J. Pòrtulas, juzgan que dicha tradición nace con la propia pólis, suministrando así al grupo una identidad y un origen comunes. Nosotros nos decantamos por esta segunda hipótesis, aunque somos conscientes de que no disponemos de datos suficientes como para poder ofrecer una solución definitiva.

[12] He aquí la gran paradoja de los estudios sobre el fenómeno de la oralidad: la mayoría de elementos que nos permiten teorizar sobre ella son textuales.

[13] Havelock, E. A., La musa aprende a escribir, trad. de L. Bredlow; Barcelona, Paidós, 1996, p. 58.

THÉMATA. Revista de Filosofía, Nº49 enero-junio (2014) pp.: 159-184

doi: 10.12795/themata.2014.i49.09 
La naturaleza de esta última era totalmente diferente a lo que dicho término nos sugiere en el presente. Su función distaba mucho de ser meramente lúdica o estética. Un poema como la Ilíada, lejos de constituir mera literatu$r a$, tal y como hoy la entendemos, forma un

"inagotable depósito de conocimientos útiles, de enciclopedia de la ética, de la política, de la historia y de la tecnología, puesta a disposición del ciudadano, para que éste la incorporase al núcleo de su utillaje educativo. La poesía no representaba lo que ahora conocemos por tal nombre, sino un adoctrinamiento que ahora se incluiría en los libros de texto y en las obras de referencia"14.

En efecto, la poesía era entonces una paideía total, la propia verdad revelada desde la esfera de lo divino a través del aedo inspirado (enthousiastikós), suministradora de un imaginario y unas disposiciones de conducta compartidas ${ }^{15}$. Por lo tanto, la poesía de la que aquí hablamos constituía un mecanismo de poder, un instrumento cohesionador y regulador que vertebraba la ciudad-estado. Dicho esto, conviene preguntarnos qué tipo de sociedad se rige mediante la oralidad.

Las hipótesis que tratan de establecer la época a la que se remontan los cantos homéricos son numerosas. Algunos hablan de la época Micénica, otros de la Edad Oscura, aunque personalmente, me parece más satisfactorio pensar que adquirieron por primera vez una forma similar a la que nosotros conservamos en el período en el que empiezan a gestarse las póleis, hacia el siglo VIII a.C. ${ }^{16}$ Éstas necesitan desde su comienzo un imaginario colectivo y unos héroes/dioses protectores y fundadores, es decir, una genealogía que explique quiénes son en tanto que comunidad. Poemas como la Ilíada proporcionan ese imaginario común, si bien siempre debemos tener en cuenta que la época que narran no les es contemporánea, sino anterior. La Ilíada y la Odisea no son espejos de la sociedad en la que se entonan, sino que ponen en juego los nómoi kaì éthea, las normas consuetudinarias y las costumbres. Lo que se transmite a través de estas obras es la propia tradición, dotando al grupo de un imaginario común. En ese sentido, y gracias a las particularidades de la oralidad, la poesía tiene un magnetismo psicológico tal que "engarza, con una cadena, los componentes y comunicadores del mensaje poético" 17 . Esta imagen de la cadena magnética resulta sugerente, pues refleja un tipo de estructuración social de-

[14] Havelock, E. A., Prefacio a Platón, trad. de R. Buenaventura, Madrid, Antonio Machado Libros, 2002, p. 41.

[15] Si bien hemos citado a Havelock, la gran mayoría de helenistas coinciden en esta cuestión, cuya importancia resulta decisiva. Sin ir más lejos, Pòrtulas lo expresa de manera igualmente clara: Cf. Pòrtulas, J., Introducció a la Ilíada, Barcelona, Fundació Bernat Metge, 2009, pp. 31-32.

[16] Adviértase que aquí nos alejamos de la hipótesis havelockiana, la cual remontaría dichos cantos a épocas más remotas.

[17] Lledó, E., «Introducción a Ion» en Platón, Diálogos I. Madrid: Gredos, 1981, p. 246.

THÉMATA. Revista de Filosofía, Nº49 enero-junio (2014) pp.: 159-184

doi: 10.12795/themata.2014.i49.09 
terminada. En una cultura oral la tradición (memoria, verdad, etc.) viene del orden de lo divino y es asumida como incuestionable, de manera irreflexiva. No hay decisión propiamente dicha, sino repetición del bagaje cultural. El poeta, de la misma manera, se limitaría a introducir mínimas variaciones en los cantos, que por su propia estructura oral no son fácilmente modelables, y a escoger un pasaje determinado que se adapte a las necesidades y requerimientos de los oyentes ante los que se sitúe en cada ocasión. Havelock acierta a ver que la cultura oral constituye un mundo pre-político, un mundo de lo concreto en el que no encontramos el espacio necesario entre el sujeto y el objeto para poder cortar con la tradición. Se trata de un mundo en el que priman lo concreto y lo inmediato, en el que lo abstracto y la historicidad están ausentes.

La Grecia más arcaica es pre-política. La decisión sobre el rumbo de la misma no es establecida de forma autónoma, sino que la tradición se repite una y otra vez como verdad sacralizada que viene impuesta desde fuera. La verdad y la legalidad se fundan en la heteronomía, pues el aedo no hace sino recitar la tradición. El poeta y el oyente concentran todas sus energías en memorizar el mensaje, en retener un saber que viene dado. En ese sentido, su intervención es escasa, pues no controlan su mundo. El aedo tan sólo puede moldear mínimamente el mensaje; no es responsable de su canto, sino que se reconoce medio, canal por el que fluye el mensaje, una pieza más, aunque clave, de aquella forma asociativa. Su lenguaje, con el objetivo de ser memorizable y creador de pautas de conducta, debe ser concreto. El aedo narra acciones y padecimientos de personas, sin dejar margen para la abstracción. De la misma manera, y como Detienne subraya, la palabra es realidad y crea realidad ${ }^{18}$; no hay momento para la reflexión, sino que el aedo y el oyente se adhieren a su ritmo y a su rima para memorizarlo. La reflexión hubiese cortocircuitado la capacidad memorística.

Sin momento para la duda, sin debate ni reflexión, no puede existir la política, la decisión autónoma que decide sobre el desarrollo del grupo:

"El aedo recitaba la tradición; los oyentes la escuchaban, la repetían y, por el recuerdo, la asimilaban. (...) El aedo ahogaba su personalidad en la recitación. (...) La pauta de conducta del aedo era idéntica a la del oyente. (...) Desde el punto de vista psicológico, se trata de un acto de adhesión personal, de compromiso total y de identificación emotiva" ${ }^{19}$.

La poesía constituía un mecanismo de poder capaz de auto-imponerse, asegurando así la supervivencia del grupo.

Una sociedad pre-política se estructura en una jerarquía social claramente diferenciada. En su tesis doctoral redactada en francés, pero publicada

[18] Detienne, M., óp. cit., p. 64: "La instauración de lo real no parece, por otra parte, diferente de la formulación de la verdad".

[19] Havelock, E. A., Prefacio a Platón, trad. de R. Buenaventura, Madrid, Antonio Machado Libros, 2002, p. 155.

THÉMATA. Revista de Filosofía, Nº 49 enero-junio (2014) pp.: 159-184

doi: 10.12795/themata.2014.i49.09 
en traducción italiana, Svenbro acierta al indicar la importancia que tiene la genealogía en los poemas homéricos:

"Lungi dall'essere un fatto 'biologico', la genealogia è un fatto sociale che deriva il suo enorme potenziale dall'imposibilità di verificarla, in una società senza scrittura, oltre un certo punto in cui, di conseguenza, il suo carattere di simbolizzazione sociale deviene sempre più trasparente" ${ }^{20}$.

En la Ilíada y la Odisea los áristoi salen victoriosos por ser áristoi y son áristoi por salir victoriosos. Las luchas, de la misma manera, siempre se resuelven según la genealogía: será aquel con una genealogía más noble el que venza. Empero, la genealogía siempre se remonta al pasado y no es verificable, sino que viene dada como verdad que se auto-impone de manera inmediata. Es decir, tiene la misma estructura que la poesía, la cual proviene de las Musas y no puede contrastarse.

Sea como fuere, la sociedad estaba mutando y este mismo paradigma pronto se quedaría anticuado. En efecto, con un desarrollo lento, pero extraordinario, la pólis conocerá un proceso de abstracción en sus relaciones y su forma de pensar que Havelock analiza atendiendo a la incursión de la letra. Ésta, que en un inicio es asimilada como una mera prolongación de la oralidad, empleándose como herramienta de trascripción del mensaje de las Musas, pronto supone un problema ontológico: lo fijado en la letra puede empezar a verse como distinto al propio hecho de decir. Se introduce una mediación en la inmediatez de la palabra cantada y, gracias al espacio abierto, queda posibilitada la separación entre el acto de decir (la enunciación/ la ilocución) y lo dicho (el enunciado/ la perlocución). Asimismo, se abre la posibilidad de distinguir entre el sujeto (autor) y el objeto (lo escrito) ${ }^{21}$. Con la letra, por tanto, aparece un signo de un orden distinto del que hasta entonces existía; aparece como algo que en sí misma no es nada, pues una letra en sí no es nada, pero paradójicamente, lo puede ser todo (puede reproducir cualquier cosa y, especialmente, la

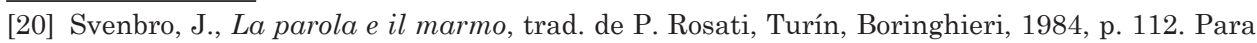
citar a los autores he empleado en todos los casos la versión castellana, salvo en aquellas obras en las que no existe una traducción. Para estas últimas, dada la proximidad del italiano y del catalán respecto al castellano, he optado por remitirme al original, sin elaborar una traducción propia. Análogamente, al citar las fuentes primarias he empleado la versión castellana en todos los casos en los que ésta existe, con el objetivo de hacer inteligible el artículo al mayor número posible de lectores. Lamentablemente, no hay ninguna traducción íntegra de la edición del Die Fragmente Der Vorsokratiker de Diels y Kranz, por lo que en algunos casos he recurrido a la traducciones italianas y catalanas de algunos fragmentos. El lector especializado encontrará todas las referencias de los fragmentos citados, por lo que podrá acudir al original griego para discutir la propuesta.

[21] Paralelamente, al constituir el texto escrito un receptáculo en el que dejar a buen recaudo la palabra de las Musas, al suministrar una memoria artificial, pero muy efectiva, las disposiciones psíquicas del aedo y del oyente se liberan de su molde anterior. Ya no es necesaria la completa adhesión, pues el texto se encarga de conservar lo proferido. Se abre así el lugar para la reflexión y la crítica.

THÉMATA. Revista de Filosofía, No49 enero-junio (2014) pp.: 159-184

doi: 10.12795/themata.2014.i49.09 
tradición oral). Se introduce en el mundo una técnica tal que en virtud de su propia estructura, la palabra ritmada queda fijada en el texto. Además, gracias a dicha fijación, eliminada la inmediatez y elasticidad del canto oral, se posibilita un análisis de lo enunciado, en tanto que realidad autónoma, lo cual resulta decisivo ya que permite que el propio texto deje de comprenderse como una prolongación de la palabra de las Musas y se muestre como una realidad autónoma. Se pasa de la continuidad sonora del discurso cantado, a un tejido de letras de alfabeto que son puramente abstractas y que, aparentemente, en nada tienen relación con las cosas sensibles (y por eso decimos que ellas, hablando de manera estricta, no son nada).

Análogamente, se propicia un proceso secularizador. Porque lo fijado en él ya no goza de la inmediatez de la palabra cantada, lo escrito puede disociarse de su carácter sagrado y debatirse. En ese momento, el texto ya no se ve como proveniente de la divinidad; el aedo o rapsoda ya no es un medio de las Musas, sino un autor y, por tanto, un hombre cuya palabra es discutible. Así, Memoria, Tradición, Verdad y toda una serie de conceptos conocerán una mutación.

Aun reconociendo esto, la innovación de la técnica escritural no es el único factor determinante. Por ejemplo, Detienne ${ }^{22}$ nos habla de una antiquísima agrupación de hombres especializados en la función guerrera que, sin la técnica del alfabeto, empleó desde tiempos muy remotos una palabra secularizada y centrada, desplegando un poder autónomo basado en la decisión de conjunto del grupo. En él, el lugar central, reservado a la tradición en un régimen oral, quedaría siempre libre para que una y otra vez pudiese ser ocupado por la determinación colectiva. En tal situación, la decisión constituye un asunto humano e inscrito en el tiempo, por lo que dicho grupo se regía ya en épocas muy remotas de manera política. Pues bien, igual que la adopción de la escritura alfabética, la estructura de aquella agrupación guerrera pudo influenciar de manera decisiva el desarrollo de las ciudades-estado.

Los factores fueron múltiples, pues eran exigidos por la propia estructuración de las nuevas póleis. Svenbro nos habla de la abstracción de las relaciones materiales en las ciudades. Este autor sugiere que la antigua ordenación genealógica fue quedándose obsoleta, en favor de una ordenación de tipo geográfica, y en ese proceso los filósofos jonios tuvieron una gran relevancia. Se estaba produciendo un cambio. Una sociedad pre-política u oral implica una determinada forma y un determinado contenido; una cultura que comienza un proceso secularizador o de antropo-centramiento, implica y requiere otra estructura (forma), pero también otra materia (prácticas). Justamente, Grecia vivió un proceso de estas características. La adopción de la moneda a finales del VII a. C. constituye un ejemplo paradigmático. En la nueva ciudad griega las relaciones sociales son cada vez más abstractas y los privilegios nobiliarios

[22] Detienne, M., óp. cit., pp. 87-108.

THÉMATA. Revista de Filosofía, Nº49 enero-junio (2014) pp.: 159-184 doi: 10.12795/themata.2014.i49.09 
empiezan a ceder ante los económicos. Aparece la moneda, un ente abstracto, que más allá de un valor real, viene cargada con un valor nominal, esto es, pactado, convenido. La reflexión y la decisión cada vez toman un lugar más importante y gracias a la propia abstracción se puede cortar con la tradición ${ }^{23}$.

Por su parte, la propia estructura de la oralidad no permite que los cantos homéricos asuman grandes alteraciones. Aunque la poesía, como el mito, es un instrumento que se moldea según las necesidades reales de su tiempo, la sociedad estaba mutando demasiado rápido como para que la tradición pudiese incorporar cambios lo suficientemente significativos en la que era su forma lingüística privilegiada, a saber, la poesía. Llegado un punto, los cantos homéricos se quedan obsoletos, es decir, pierden su funcionalidad, convirtiéndose en un enigma incomprensible para los ciudadanos. Paralelamente, el polítes puede desmarcarse de esa tradición, al empezar a verla como homérica, es decir, como el producto de un autor y no de la divinidad. El hombre puede cortar con una tradición con la que ya no se siente identificado por haber cambiado el contexto material al que se circunscribe. Cuando aquel bagaje cultural ya no es compatible con la ciudad, cuando ya no le aporta ciertos beneficios, caben dos opciones: suprimirlo o manipularlo de tal forma que recupere su vigencia.

A este respecto, el siglo VI es crucial, pues en él se despliega uno de los procesos más significativos para comprender el cambio que se está produciendo en la forma de estructuración de la ciudad-estado. En lo sucesivo analizaremos tres momentos de ese proceso que se desarrolla en el VI a. C.

\section{La fijación de los cantos homéricos}

Determinar el origen de los cantos homéricos entraña una tarea complicada y controvertida, por lo que nos limitaremos a recoger la hipótesis que más nos satisface. Análogamente, existe una gran discusión sobre cómo y cuándo se fijan a través de la letra y por primera vez los cantos homéricos. Éstos, como ya hemos visto, constituyen un instrumento y, por tanto, son usados en función de las necesidades de la sociedad en la que se encuadran. No eran unitarios y fijos, sino que variaban en función del contexto y de la ciudad; se recitaban ante un público real y en situaciones muy diversas: en banquetes nobiliarios, en celebraciones de carácter más popular, etc. No obstante, más allá de dichas contingencias, parece que el agón constituía un elemento central que atravesaba aquella sociedad. Los certámenes representan una costumbre arcaica de gran raigambre, que se prolongó durante largo tiempo. La sociedad griega era una

[23] Adviértase que la alusión al dinero (oro) ya es empleada por Heráclito, para señalar su naturaleza abstracta e intercambiable: "Todas las cosas se cambian recíprocamente con el fuego y el fuego, a su vez, con todas las cosas, como las mercancías con el oro y el oro con las mercancías" (Fragmento DK 22 B 90, en Kirk, Raven y Schofield, Los filósofos presocráticos, trad. de J. García Fernández.; Madrid, Gredos, $2^{\text {a }}$ reimpresión a la segunda edición, 1999, p. 288).

THÉMATA. Revista de Filosofía, Nº 49 enero-junio (2014) pp.: 159-184

doi: 10.12795/themata.2014.i49.09 
sociedad sumamente competitiva. Ya en los textos homéricos vemos cómo los héroes luchan entre sí para conseguir el reconocimiento, la gloria (kléos). En el período clásico encontramos la misma estructura competitiva en las disputas retóricas, la tragedia ática o en la oratoria. Análogamente, la poesía épica también se enmarcaba, dependiendo de la ocasión, dentro de ese esquema agonal. El agón era una lucha de poder, un certamen en el que dos o más personas competían por obtener la gloria. Pues bien, en la sociedad griega arcaica se celebraban certámenes de poesía en los que diferentes poetas pugnaban entre sí por la victoria.

Conocemos pocos detalles al respecto; no sabemos si se fijaba un motivo y los aedos o rapsodas escogían el pasaje que mejor les pareciese o si simplemente cada poeta elegía por sí mismo qué fragmento de la vasta tradición entonar. En cualquier caso, parece que estos certámenes resultaban muy comunes en las ocasiones festivas. Tenemos indicios de que los tiranos del siglo VI a.C. fomentaron considerablemente tales disputas de forma que, en dicho siglo y favorecida por tales circunstancias, una gran cultura musical homérica tomó cuerpo. Rivalizando entre sí, un amplio grupo de poetas se dedicaron a recitar a Homero, de manera que los cantos del ciego de Quíos proliferaron y adquirieron una extensión descomunal ${ }^{24}$. Se han propuesto diferentes hipótesis, pero en cualquier caso parece que los cantos homéricos fueron trascritos a la escritura alfabética en ese mismo siglo, quedando fijados en un vastísimo texto ya inamovible. Dos de las hipótesis con más adeptos son la de la Recensión pisistrátida o Hipótesis ateniense y la Oral dictated text de A. B. Lord ${ }^{25}$. En cualquier caso, parece que la unificación definitiva del texto tiene que ver con el monopolio que logró una pólis, a saber, Atenas, respecto a la tradición griega. De tal forma, fijando el texto hizo suya la versión canónica y, en un cierto sentido, toda la tradición de la cultura griega, esto es, su imaginario colectivo. La tradición, hasta entonces oral, queda apresada en el texto, produciéndose un cambio decisivo: el estandarte de la oralidad, la propia tradición anterior, queda fijada, petrificada. Paralelamente, el contexto social cambia en escasos siglos, ya que la estructura de la pólis evoluciona desde su nacimiento: se avanza de una era pre-política a la política y de la repetición de la tradición a la historicidad, en un marco en el que las relaciones se tornan cada vez más abstractas.

[24] No lo hemos advertido, pero en cualquier caso ha de aclararse que no creemos que un tal Homero existiese realmente nunca. En sus cantos él mismo desaparece para entonar la tradición. Es más, los aedos y rapsodas atribuirían a Homero sus poemas para otorgarles con ello la etiqueta de la excelencia, pues "lo homérico" no sería tanto lo genuinamente homérico, sino la mejor poesía de tales características. La figura del autor cambia gracias a la escritura. En la Grecia arcaica no tiene sentido hablar de plagio. Sólo cuando la noción de "autoría" empiece a perfilarse comenzará la re-construcción de la figura de Homero, hacia el VI a. C. Esto lo veremos enseguida.

[25] Lord, A. B., "Homer's Originality: Oral Dictated Texts" en Transactions of the American Philological Association 84, pp. 124-134.

THÉMATA. Revista de Filosofía, Nº49 enero-junio (2014) pp.: 159-184

doi: 10.12795/themata.2014.i49.09 
La fijación de la tradición mediante la escritura comporta unas consecuencias decisivas. La oralidad, poco a poco, empieza a perder el monopolio del poder y de la paideía. La palabra del aedo y su propia figura, su prestigio social, comienzan a deteriorarse. La cultura está conociendo un antropo-centramiento, la perspectiva empieza a aparecer en escena y el debate ocupará el centro de la ciudad. De forma gradual, la verdad deja de constituir algo que proviene del orden de lo sagrado para llegar a ser una cuestión que ha de convenirse entre los hombres a través del diálogo o las disputas retóricas.

Como dijimos, en el momento en el que tenemos un texto escrito se abre la condición de posibilidad de ver lo enunciado y fijado en un texto como un objeto autónomo. El escrito deja atrás la inmediatez de la oralidad y puede entenderse como objeto autónomo y criticable. Al considerarlo un producto, se puede ver también como el objeto de un sujeto y, de tal forma, en el siglo VI comenzarán toda una serie de críticas y disputas cruciales. De hecho, pensamos, con Pòrtulas, que

"la fixació gradual del text, la invenció del seu autor i les fases més antigues d'exegesi se'ns apareixen com a tres processos que es descabdellaren d'una manera paral lela, com les línies convergents de una mateixa figura" ${ }^{26}$.

Solamente gracias a la fijación mediante el texto es posible una crítica tan severa y cobra tal importancia la construcción del autor. Por eso, en parte, creemos que la fijación definitiva del texto homérico debió de producirse en el siglo VI:

"Abans del segle VI a.C., les notícies que els autors grecs transmeten sobre Homer són imprecises, erràtiques i infreqüents, si no és que falten totalment. En la «construcció d'Homer» (...) el paper crucial sembla pertànyer a l'edat de Xenòfanes de Colofó i Heràclit efesi: dos pensadors o "proto-filòsofs», i això també resulta significatiu. Aquesta "invenció d'Homer» sembla que ha tingut sobretot finalitats polèmiques. Comencem a sentir parlar d'«Homer» quan alguns pensadors que estan en desacord amb la vasta popularitat d'aquesta poesia -i, especialment, amb la imatge que ofereix de la divinitat-comencen a suggerir que «Homer» hauria d'ésser foragitat dels certàmens poètics a garrotades, o que està patint tots els turments de l'Hades, com a càstig de les seves blasfèmies. Resultava més còmode, a l'hora d'atacar els vastos poemes tradicionals, disposar d'una figura d'Autor-responsable (potser una novetat, en ella mateixa), a fi de poder-li carregar els neulers. No es tracta, solament, que la figura d'Homer es trobi en el centre de totes les polèmiques de l'Època Arcaica grega. Convé anar un pas més enllà: la figura d'Homer sembla que va cristal litzar a partir d'aquestes polèmiques"27.

Lejos de pensar como Havelock que todo el cambio social constituye un efecto de la aparición de la escritura, juzgamos que fue el fruto de la interrelación de una amplia serie de factores materiales. La letra, en parte, fosiliza su contenido y con ello la propia capacidad de innovación del rapsoda, que por

[26] Pòrtulas, J., óp. cit., p. 43.

[27] Pòrtulas, J., óp cit., p. 425.

THÉMATA. Revista de Filosofía, Nº49 enero-junio (2014) pp.: 159-184

doi: 10.12795/themata.2014.i49.09 
sí misma era escasa, se vio reducida a la nada. La sociedad estaba mutando, mientras que el texto, en determinado momento, quedó fijado, rígido. Además, la moral plasmada, por ejemplo en la Ilíada, no resultaba compatible para la nueva estructuración de la pólis y sus condiciones materiales, siendo su moralidad inadmisible para el nuevo ciudadano. La Ilíada glorifica un sistema objetivo de valores en el que el héroe continuamente aspira a la exclusividad, persiguiendo siempre sobresalir por encima de todos. Por tanto, es inevitable que los diferentes héroes entablen luchas a muerte, pues cada uno tiene razón en sí mismo, cada cual está obligado a luchar por su propio kléos. Es de justicia buscar esa gloria y, sin embargo, no pueden obtenerla todos por igual, pues a menudo ésta sólo se alcanza con la victoria sobre el vencido. En el esquema homérico no puede haber un proyecto compartido en el seno de una ciudad, pues la gloria de uno es incompatible con la del otro. El ideal heroico no es compatible con la nueva mentalidad que aparece alrededor del siglo VI y la estructura de la nueva pólis. En parte gracias a su fijación por escrito se hace posible tomar distancia respecto a la tradición y que nazca un proto-sujeto que se vea a sí mismo ajeno a dicha herencia cultural y que, por tanto, decida cambiarla o criticarla. Algunos de los representantes de la nueva mentalidad critican, pues, según el nuevo marco social, la tradición que hasta entonces imperaba. Las nuevas estructuras sociales y necesidades materiales reclaman otro tipo de instrucción y una nueva cosmovisión.

En el siglo VI se fija el texto, se construye la figura de Homero y aparecen sus detractores y sus defensores. Se trata de un proceso necesario, en tanto que es la manifestación de un cambio social. Una vez aclarada su razón de ser, pasemos a atender una de las primeras y más feroces críticas lanzadas contra la tradición homérica.

\section{Jenófanes y la crítica a la tradición}

La introducción de la escritura alfabética junto a toda una serie de factores fomenta un proceso de abstracción en la estructura relacional griega y en su imaginario. A este respecto, nos parece que la fijación por escrito de las epopeyas homéricas supone un momento crucial, pues ayuda a truncar la incuestionabilidad de la tradición y de los propios cantos homéricos. La sociedad está en continuo desarrollo y para los nuevos pensadores la verdad empieza a identificarse con una especie de consenso falsable. Por un lado, como indica Vernant ${ }^{28}$, el concepto de méson se está haciendo central en la pólis. Por otro, el hombre empieza a pensar que el abismo que lo separa de la esfera divina es demasiado profundo como para hablar de una relación privilegiada con ésta y de una verdad que de ella provenga. El ciudadano toma consciencia de que su

[28] Cf. Vernant, J.-P., óp cit.

THÉMATA. Revista de Filosofía, Nº49 enero-junio (2014) pp.: 159-184 doi: 10.12795/themata.2014.i49.09 
conocimiento, a diferencia del divino, ni es omnisciente ni inmediato. Por eso, la ciudad ha de reservar su centro, dejarlo momentáneamente vacío, para que los hombres, tras convenir hipótesis y decisiones, funden allí la verdad. En cualquier caso, la naturaleza de la alétheia ha mutado ya que, despojada de su antigua incuestionabilidad, solamente la contrastación y la puesta en práctica pueden verificar o refutarla ${ }^{29}$ : la verdad debe construirse mediante el consenso humano. Se requiere despejar el centro de la comunidad, en tanto que condición de posibilidad para la propia decisión y el acuerdo social. Así, se establece un corte respecto a la inmediatez de la oralidad; el hombre empieza a tomar consciencia de su papel en el mundo y asume la responsabilidad. Se produce una secularización ${ }^{30}$ decisiva en la que la tradición, la verdad y el conocimiento son despojados de su aureola sacra, pasando a ser asuntos humanos y, por tanto, discutibles.

La pólis está erigiéndose en un mundo diferente al del período arcaico. Lo concreto cada vez cede más terreno en favor de lo abstracto y la noción de "individuo" pronto empieza a tomar fuerza. Frente a la ordenación jerárquica nobiliaria anterior, la ciudad-estado avanza hacia formas más igualitarias.

Cuando la verdad y la tradición son paulatinamente desposeídas de su carácter divino, empiezan a ser objeto de críticas. Análogamente, el oficio de rapsoda se carga de una connotación despectiva. En el siglo IV a.C. esta profesión tiene unas implicaciones muy negativas para intelectuales como Platón o Jenofonte, pero la crítica al canto del rapsoda se remonta al siglo VI. Curiosamente, Jenófanes de Colofón, presumiblemente un rapsoda, fue uno de los primeros en criticar la educación que transmitían sus colegas.

Jenófanes se remonta al VI a.C., situado de pleno en el proceso de cambio que describimos. Diógenes Laercio nos dice de éste en DK 21 A1 que "escribió en verso épico así como elegías y yambos contra Hesiodo y Homero, poniendo en solfa lo que decían acerca de los dioses; y también recitaba él mismo sus propios poemas [allà kaì autòs errapsóidei tà autoûj’31. Efectivamente,

[29] Svenbro en la p. 93 de su La parola e il marmo nos habla de la relevancia que tuvo el cambio en la representación, el cual en parte fue favorecido por el avance de la cartografía. Con la cartografía se producirá un salto hacia la abstracción; frente al pensamiento de la oralidad, concreto, ahora nos enfrentaremos a un pensamiento proposicional. La operación proposicional consiste "nell trarre da due o più proposizioni, poste come vere o false in astratto (independentemente cioè dal loro contenuto) dei "raggruppamenti" essi stessi determinati nella loro verità o falsità". El conocimiento humano es limitado y por eso la única forma de proceder es hacer hipótesis y contrastarlas posteriormente. Es el consenso, la verosimilitud, lo que le da a algo el carácter de verdadero y no ya su mera procedencia.

[30] Adviértase que el proceso del que aquí damos noticia, si bien por una parte responde a una secularización, por otra, posibilita el comienzo de un nuevo tipo de religiosidad mucho más conforme a la de los siglos posteriores, a saber, la que sitúa a la divinidad en una transcendencia absoluta. Por eso, la secularización no es ni mucho menos total, sino que con ella nace una nueva forma de religiosidad, diversa del politeísmo antropomórfico.

[31] Diógenes Laercio, Vidas y opiniones de los filósofos ilustres, trad. y notas de L. Bredlow, Madrid, Lucina, 2010, pp. 335-336.

THÉMATA. Revista de Filosofía, No 49 enero-junio (2014) pp.: 159-184 doi: 10.12795/themata.2014.i49.09 
si Jenófanes errapsóidei, habremos de reconocer que era un rapsoda. Empero, la expresión "autòs errapsóidei tà autoû" resulta significativa. Los rapsodas ${ }^{32}$ cuando cantaban atribuían la autoría de su canto a un tercero, ya fuesen las Musas u otro poeta. En cambio, el colofonio recitaba su propio mensaje. Como sabemos, los rapsodas eran unos de los educadores más relevantes de la Grecia de aquel tiempo. Su cultura todavía estaba impregnada por la oralidad y la mayoría de ciudadanos seguía aceptando acríticamente las enseñanzas homéricas que los rapsodas procuraban. Jenófanes empleó el mismo canal, el de la poesía, para llevar a cabo su aleccionamiento. El medio poético debía ser, sin duda, uno de los canales privilegiados para la divulgación. No obstante, el contenido de sus versos es enteramente dispar a lo que cabría esperar de un rapsoda, como podemos comprobar en el texto que acabamos de citar. Jenófanes ataca la concepción homérica de la divinidad, la cual era conservada y continuada por los propios rapsodas. El ataque, pues, se dirige contra la tradición que sus colegas preservan y reproducen, pero además, contra su propia sociedad y las instituciones que sostenían a un gran número de rapsodas, suministrándoles su bion o sustento. Al adquirir consciencia de que entre su sociedad y la tradición homérica hay un corte insalvable y juzgando que aquella cosmovisión tradicional no era sostenible ni saludable, Jenófanes asume la realidad de su tiempo, comprende el marco social en el que vive y quiere obrar en consecuencia. Él, en efecto, se sitúa en otro paradigma y percibe el conocimiento, la tradición, la educación, la divinidad, el hombre y toda una serie de conceptos capitales desde la nueva óptica que permite su tiempo, la cual es incompatible con el marco social anterior. La razón de esto ya la hemos adelantado, pero expongámosla a continuación con mayor claridad.

Los cantos homéricos constituían una enciclopedia que educaba a toda la sociedad, que daba cuenta de la situación presente y que dotaba al mundo de un sentido. Sin embargo, en torno al siglo VI el sentido que proporcionaban ya no era inteligible para los ciudadanos. Las lentes que ofrece Homero ya no sirven para ver satisfactoriamente el mundo y se requiere de unas gafas nuevas. Pues bien, sostenemos que Jenófanes asume el reto de suministrar un nuevo modelo epistemológico al reconocer la limitación cognoscitiva inherente al humano. Se asume que el hombre siempre entiende desde una perspectiva limitada y que, por ello, su conocimiento tiene un carácter criticable y progresivo. Los rapsodas contemporáneos a los que ataca se limitan a reproducir un saber que ha quedado fijado y que, según él, no es sino contraproducente para la ciudad. Frente a lo concreto y a la inmediatez de la poesía épica anterior, se

[32] En el presente artículo evitaremos distinguir entre rapsodas y aedos. En cualquier caso, tampoco es clara la distinción que hay entre ambos. En principio, parece que el aedo atribuía su canto a las Musas u otras divinidades, mientras que el rapsoda refería la autoría del canto a algún otro poeta o texto anterior. Dicho esto, no seremos exhaustivos en el empleo de los términos, pues en la práctica la distinción no era tan neta.

THÉMATA. Revista de Filosofía, Nº49 enero-junio (2014) pp.: 159-184

doi: 10.12795/themata.2014.i49.09 
abre la vía de un pensamiento proposicional y mediato. Jenófanes proclama la imposibilidad de acceder a un conocimiento inmediato y total, el cual está reservado al dios trascendente del que nos habla, a saber, un dios enteramente diferente al de los cantos homéricos.

Para Svenbro, si bien las traducciones de este texto han acostumbrado a velar el mensaje que el colofonio quería transmitir, uno de los fragmentos que mejor expresa este cambio epistemológico es el fragmento DK 34 . Por ello, Svenbro recoge la traducción de Riviere, proponiéndola como la más conveniente para elaborar una re-lectura:

"Nessuno sa né mai saprà la verità (to saphes) sia riguardo agli dei sia riguardo a tutte le cose di cui parlo. Infatti, se anche qualcuno arrivasse per caso a descrivere perfettamente un processo compiuto (tetelesmenon), nondimeno non lo saprebbe lui stesso: poiché su tutte le cose è dato avere solo una conoscenza congetturale (dokos)"33.

Muchas de las traducciones han hecho del dókos la "opinión”, cargando el término de un matiz negativo o, al menos, subrayando su inferioridad frente al conocimiento (epistéme $)^{34}$. Siendo así, el sentido de la frase varía notablemente, resultando crucial la elección filológica entre una y otra propuesta.

A tenor del fragmento, la contraposición entre una y otra epistemología descansa en la divergencia entre tetelesménon (proceso completado o realizado) y dókos (reconstrucción conjetural). Dicha distinción va ligada a la incursión del pensamiento proposicional al que ya hemos aludido. Previamente nos referimos a la ascendente importancia de la moneda en la ciudad-estado, que está dividida entre su valor real y su valor convenido o nominal. Empero, en último término, su valor real de nada sirve en la ciudad y lo único que cuenta es el valor que convencionalmente se le asigna. "Chrémata dókima" (bienes de valor convenido) se refiere a la moneda, pero al valor que cada ciudad le asigna de forma convencional. Lo característico de la moneda es su valor nominal. Expresado diversamente, más allá del plano de lo inmediato, nos encontramos con el consenso humano, con lo que acordamos que es la verdad de cada cosa. En consonancia con esto y en el ámbito de la deliberación democrática en la pólis, Svenbro destaca como frase significativa "édoxe $e^{35}$ tối démó $i$ ", que puede traducirse por "al pueblo le pareció conveniente", es decir, "el pueblo ha decidido". Otra vez nos topamos con la misma estructura. En un régimen democrático los hombres han de congregarse para decidir sobre ellos mismos y el mundo en el que viven. Puesto que en la pólis hay diferentes intereses, perspectivas y anhe-

[33] Fragmento DK 21 B 34, en Svenbro, J., óp cit., p. 91.

[34] Por ejemplo, la versión española del Kirk, Raven y Schofield propone la siguiente traducción: "Ningún hombre conoció ni conocerá nunca la verdad sobre los dioses y sobre cuantas cosas digo; pues, aun cuando por azar resultara que dice la verdad completa, sin embargo, no lo sabe. Sobre todas las cosas [o sobre todos los hombres] no hay más que opinión”.

[35] Adviértase que dókos, dókimos y édoxe provienen de una misma raíz.

THÉMATA. Revista de Filosofía, Nº 49 enero-junio (2014) pp.: 159-184 doi: 10.12795/themata.2014.i49.09 
los, resulta imposible saciarlos todos, es decir, lograr su tetelesménon, en tanto que cumplimiento total y efectivo de la voluntad popular. Por eso, al adquirir consciencia, no ven más remedio que dirigir sus esfuerzos a la consecución de un consenso, el cual debe fundar su legitimidad en la voz de la mayoría.

Dókos, por tanto, término que podría traducirse de muy diversas maneras, no tendría un valor negativo para Jenófanes, sino todo lo contrario ${ }^{36}$. Comprende que el conocimiento humano funciona como un enunciado proposicional: primero es expresado y luego le otorgamos un valor de verdad o falsedad en función de su verosimilitud, es decir, según lo contrastemos con la realidad. Para el hombre la verdad siempre tiene que ver con una especie de acuerdo; la verdad no es dada e incuestionable, sino discutible y variable.

El filósofo colofonio, por tanto, ve la necesidad de distanciarse del modelo cognoscitivo anterior en favor de uno novedoso. En el nuevo paradigma, ningún hombre tiene acceso a la verdad absoluta y, por eso, juzga como verdadero lo que así se lo parece ${ }^{37}$. En esa línea, sostiene que el único camino epistemológico posible para el hombre es la investigación, una constante tarea de persecución, depuración y progreso hacia la verdad: "ciertamente los dioses no revelaron todas las cosas desde el principio a los hombres, sino que, mediante la investigación, llegan éstos con el tiempo a descubrir mejor"38. Por eso, al tetelesménon homérico le contrapone el dókos. El conocimiento supone, ahora sí, un problema que debe ser abordado. El antiguo aedo o rapsoda decía recibir un saber completo e inmediato gracias al entusiasmo. Según el nuevo paradigma, en cambio, sólo un dios transcendente puede tener un conocimiento tal. Adviértase que se trata de un dios de carácter transcendente y abstracto, cuya naturaleza difiere profundamente de la de los dioses antropomórficos de los poemas homéricos. Dice Jenófanes: “(Existe) un solo dios, el mayor entre los dioses y los hombres, no semejante a los mortales ni en su cuerpo ni en su pensamiento" 39 . En efecto, es un dios transcendente, diferente y superior a los hombres y a las divinidades del Panteón tradicional. Un dios que "todo él ve, todo él piensa y todo él oye" 40 , plenamente compatible con la estructura de la pólis y sus exigencias morales y universalizadoras. Una divinidad que, como

[36] Nótese que el término dóxa también deriva de la misma raíz. Es conocido que Platón delimita una contraposición entre dóxa y epistéme, que ha llevado a muchos a cargar el término dóxa de un matiz negativo, hasta el punto de ligarlo a aquello que es inferior al conocimiento o incluso a la falsa opinión. No obstante, incluso en Platón, resulta erróneo interpretar que la dóxa siempre esté revestida de una connotación negativa. Como observamos, en Jenófanes, de hecho, parece que sucede todo lo contrario. En su dókos no sólo encontramos el reconocimiento de la finitud humana, sino, también, el afán de superarla.

[37] Cf. el fragmento DK 21 B 35, en Kirk, Raven y Schofield, óp. cit., p. 262.

[38] Fragmento DK 21 B 18, en Kirk, Raven y Schofield, óp. cit., p. 262.

[39] Fragmento DK 21 B 23, en Kirk, Raven y Schofield, óp. cit., p. 249.

[40] Fragmento DK 21 B 24, en Kirk, Raven y Schofield, óp. cit., p. 249.

THÉMATA. Revista de Filosofía, Nº49 enero-junio (2014) pp.: 159-184

doi: 10.12795/themata.2014.i49.09 
nos dice el fragmento DK 21 B 26+25, "siempre permanece en el mismo lugar, sin moverse para nada, ni le es adecuado el cambiar de un sitio a otro, sino que sin trabajo, mueve todas las cosas con el solo pensamiento de su mente" ${ }^{41}$. Solamente él es perfecto y acabado, motivo por el cual está en reposo y todo lo puede y lo sabe sin necesidad de movimiento alguno. La vía del tetelesménon es exclusiva de dicha divinidad. Los humanos, en cambio, estamos condenados al esfuerzo, a las conjeturas y al progreso hacia una verdad cada vez más fiable. El salto ontológico y epistemológico entre los hombres y dios es absoluto y, por eso mismo, ya no tiene sentido una omnisciencia recitada por un aedo entusiasmado. Para el aedo o rapsoda el conocimiento no suponía un problema, pues lo expresado se lo insuflaba la Musa,

\footnotetext{
"e la Musa era la rappresentazione collettiva del controllo sociale che determinava la pur mutevole "verita"dell'aedo. Il Dio di Senofane è molto diverso: immutabile, non ispira el filosofo, che solo "cercando" raggiungerà la conoscenza congetturale. Tra Dio e uomo vi è una distanza incolmabile, una frontiera insormontabile. In effetti, pare proprio che un tale Dio non rappresenti altro che la possibilità teorica di una conoscenza totale: quella obiettiva visione d'insieme, inaccessibile all'uomo" ${ }^{42}$.
}

Ésta es la fractura que introduce Jenófanes y que según Svenbro viene posibilitada por la ciencia jónica. Los primeros fisiólogos sometieron la verdad a unos criterios propios de verificación tras comprender que no se puede predicar la misma epistemología de un dios omnisciente y de los hombres. De esta guisa, la verdad pasa a constituir una especie de reconstrucción conjetural que será aceptada como semejante a la realidad, es decir, como verdadera para el hombre, hasta que otra teoría se amolde más satisfactoriamente a ésta o se demuestre su falsedad ${ }^{43}$. Por su parte, dios pasa a ser la posibilidad misma de un conocimiento absoluto, situado en una esfera que nos resulta totalmente inalcanzable.

Jenófanes no está dispuesto a admitir una educación como la homérica; en el contexto de la pólis del siglo VI ya no puede aceptar un saber enteramente heterónomo. La ciudad-estado está volviéndose más diversa, el trabajo se está especializando de forma progresiva y las relaciones sociales se multiplican a la par que se hacen más impersonales. La pólis cada vez es más igualitaria y, si la verdad es discutible, el derecho de palabra empezará a cobrar un papel fundamental. El rapsoda puede tomar la palabra, en efecto, pero también un tercero para criticarlo. El colofonio no puede asumir el mundo homérico, pues una colectividad ordenada y el ideal del hombre heroico son incompatibles, de modo que al habitante de la pólis los motivos homéricos le resultan cada vez más lejanos. Por eso, porque se han vuelto algo excesivamente extravagante,

[41] Fragmento DK 21 B 26+25, en Kirk, Raven y Schofield, óp. cit., p. 249.

[42] Svenbro, J., óp. cit., pp. 95-96.

[43] Recuérdese el fragmento DK 21 B 35.

THÉMATA. Revista de Filosofía, Nº49 enero-junio (2014) pp.: 159-184 doi: 10.12795/themata.2014.i49.09 
posiblemente hacia el siglo VI, los poemas homéricos, además de ser reproducidos, tendrían que ser comentados o incluso interpretados. Según Pòrtulas,

"els rapsodes de l'Època Arcaica Tardana, a més a més de recitar els poemes homèrics, els comentaven i els il lustraven amb observacions de diverses menes (...). L'originalitat de Xenòfanes estava en el fet que els seus comentaris, en comptes d'ésser, com de consuetud, encomiàstics, blasmaven d'una manera molt aspra tant Homer com Hesíode, i criticaven les concepcions que els antics poetes s'havien forjat de la divinitat"44.

Obviamente, aquella sociedad estaba cambiando paulatinamente y las críticas del de Colofón debían irritar a la mayoría de sus contemporáneos, reacios a una crítica tan feroz de la tradición.

Sea como fuere, el filósofo había visto el abismo abierto entre la estructura de su mundo y la del de los cantos homéricos. La moralidad de los héroes y de los dioses homéricos no podía ser la de los ciudadanos, pues, de lo contrario, el orden social se desmoronaría. En consecuencia, emprendió una dura crítica contra el propio contenido de aquellos poemas y los comportamientos de los dioses y los héroes. Veamos a continuación algunas de las críticas más significativas.

Jenófanes ataca a dos de las fuentes más autorizadas de la tradición sosteniendo que "Homero y Hesíodo han atribuido a los dioses cuantas cosas constituyen vergüenza y reproche entre los hombres, el robo, el adulterio y el engaño mutuo" 45 . Los dioses y héroes homéricos no están hechos para la convivencia en la pólis. El sistema de nómoi kai éthea que reflejan los poemas épicos ya no es compatible ni semejante al de la ciudad-estado. Por razones materiales y formales, Jenófanes ya no puede reconocer su mundo en el dókos tradicional. Frente a una jerarquía divina basada en la genealogía, Jenófanes propone una isonomía entre los dioses que sea semejante a la igualdad que debe haber en la ciudad. Más relevante todavía, más allá de las divinidades tradicionales, las exigencias de universalidad y abstracción de la ciudad-estado reclaman un dios transcendente como al que antes nos hemos referido. El dókos homérico, juzga el colofonio, se funda en supersticiones de la gente; son un constructo formado a partir de creencias irreflexivas. Svenbro nos sugiere que, en su crítica a Homero y Hesíodo, Jenófanes los sitúa junto a los bárbaros, vinculados con las supersticiones infundadas. "Se la polis rappresenta per Senofane l'abbandono di dokoi superstiziosi e falsi, essa nel contempo costituisce, rispetto al passato, un vero e proprio progresso, di cui il filosofo intende garantire la continuazione" 46 . Ya lo vimos en el fragmento DK 21 B 34: Jenófanes cree que avanzamos a través de las conjeturas y la contrastación. La homérica sería otra conjetura más, pero para él resulta evidente que no es semejante a la realidad, sino que sólo se aguan-

[44] Pòrtulas, J., óp cit., p. 43.

[45] Fragmento DK 21 B 11, en Kirk, Raven y Schofield, óp cit., p. 247.

[46] Svenbro, J., óp cit., p. 99.

THÉMATA. Revista de Filosofía, Nº49 enero-junio (2014) pp.: 159-184 doi: 10.12795/themata.2014.i49.09 
ta por una superstición absurda. Consecuentemente, criticará la concepción antropomórfica de la divinidad que tanto los bárbaros como los poemas homéricos sostienen ${ }^{47}$. Jenófanes no ignora que el suyo es también un conocimiento humano y por tanto conjetural y, sin embargo, lo juzga superior por estar de acuerdo con la realidad, por asemejarse a ésta y por no haber sido falsado por ella. En cambio, lleva al absurdo las concepciones antropomórficas y pre-políticas atribuidas a Homero. En definitiva, Jenófanes falsea el dókos homérico.

En la nueva ciudad-estado conviven hombres y su palabra debe tener, en principio, el mismo derecho. Acorde con esto, según la epistemología del de Colofón, no es posible detentar un discurso y un conocimiento privilegiados e incuestionables. En la pólis coexisten diferentes fuerzas y sólo el consenso podrá asegurar un pacto.

\section{El rapsoda se defiende: Teágenes de Regio y la alegoría homérica}

Acabamos de ver que Jenófanes, no estando de acuerdo con la tradición, propuso otra. Además, su crítica, pese a que tal vez no fuera muy popular, no debió ser la única y otros intelectuales como Heráclito de Éfeso también atacaron a Homero y a la paideía de los rapsodas ${ }^{48}$ ya que estaban convencidos de que aquella educación era perjudicial para la pólis.

Entre tanto, Homero seguía vivo gracias a que numerosos rapsodas habían asumido la tarea de reproducir e interpretar sus cantos. En el siglo VI las ocasiones festivas y las competiciones poéticas se multiplicaron. Los rapsodas obtenían su sustento gracias la recitación, pero ataques como el de Jenófanes ponían en entredicho la relevancia y la reputación del oficio de rapsoda. Si la gente se convenciese de que, efectivamente, Homero cantaba cosas impías, no continuaría reclamando su recitación, sino todo lo contrario y así los rapsodas homéricos hubiesen visto arrebatado su medio de vida. En consecuencia, se vieron empujados a emprender una defensa de Homero.

El problema no era insignificante, pues al haber sido fijados por escrito, los cantos ya no podían ser moldeados. Lo escrito era inalterable y las acciones narradas eran, bajo la nueva perspectiva moral, inaceptables. Siendo así, una de las pocas vías que permitían practicar una defensa de Homero era la que más adelante se conoció como el "alegorismo". La alegoría consiste en decir una cosa para hacer comprender otra. Pues bien, los alegoristas defienden que los textos homéricos no tienen que ser interpretados literalmente, sino alegóricamente. Según éstos, Homero dijo una cosa para que, en realidad, la gente comprendiese otra. Los rapsodas se aferran a la defensa alegórica y atacan a

[47] Cf. Fragmentos DK 21 B 14; DK 21 B 16; y DK 21 B 15, en Kirk, Raven y Schofield, óp. cit., p. 247.

[48] Cf. Fragmento DK 22 B 42.

THÉMATA. Revista de Filosofía, Nº 49 enero-junio (2014) pp.: 159-184 doi: 10.12795/themata.2014.i49.09 
los críticos de Homero tachándolos de ignorantes, es decir, de no comprender el significado profundo (hypónoia) de sus poemas. Los cantos petrificados en la letra no han quedado tan fosilizados como pensábamos, pues nace la interpretación del texto, a saber, la hermenéutica. El autor, si es que alguna vez existió, ya no estaba presente para aclarar cuál fue su intención al crear los poemas. Por tanto, el rapsoda opone al dókos del colofonio un nuevo dókos. El filósofo plantea su conjetura en plena consonancia con la libertad de palabra (parrésía) de la pólis, es decir, ofrece su perspectiva. Empero, los alegoristas censuran dicha crítica haciendo gala de la misma libertad de palabra y apoderándose de la posibilidad de proponer otro punto de vista distinto. Según la defensa de los rapsodas, acusar a Homero de impío es propio de gente rústica que es incapaz de percatarse del significado real y profundo de su poesía.

Dicho esto, parece plausible que la apología alegórica naciese como reacción contra la crítica a Homero, es decir, como la defensa de los rapsodas de su propio medio de vida. No se trata de una hipótesis demostrada, pero contamos con una serie de indicios que permiten sospecharlo. En un escolio a la Ilía$d a$, Porfirio anota que la defensa alegorizante de Homero es un método "molt antic: procedeix de Teàgenes de Règion, el primer que va escriure sobre Homer (hos prôtos égraphe perì homérrou), i es fonamenta en la dicció (apò têes léxeós)" 49 . Según nos dice Diógenes Laercio, Jenófanes se exilió de su patria yendo, entre otros sitios, a Zancle, ubicada muy cerca de Regio. A esto hemos de añadirle la noticia de Taciano (DK 8 A1), que los aproxima cronológicamente, fijando el acmé del de Regio hacia el 520 a.C.: "I primi a studiare la poesia, la genealogia e la data di Omero, furono Teagene de Reggio, contemporaneo di Cambise, Stesimbroto di Taso e Antimaco di Colofone" ${ }^{" 50}$. Por tanto, lo más plausible es suponer que hubo un período en el que Jenófanes y Teágenes vivieron muy próximos entre sí, apenas distanciados por la decena de kilómetros que separan los extremos del Estrecho de Mesina. De ser cierto, lo más probable es que Teágenes estuviese al corriente de las críticas del filósofo. Debido a la fijación del canto homérico y a sus críticos, pero también a causa de las nuevas condiciones de la ciudad-estado, era apremiante realizar una exégesis de Homero, pues sólo así podía conservarse su vigencia, esto es, su sentido en la pólis. Los rapsodas, movidos por necesidades materiales, a saber, garantizarse el sustento, reaccionan y "ora, l'arma più efficace per difendere il testo ormai inmutabile, era il metodo interpretativo"

Por tanto, aunque la posición de los alegoristas se confronta a la de Jenófanes, ambas se sitúan de acuerdo con la nueva estructuración social y política. Teágenes responde al dókos del colofonio con su misma moneda. A este

[49] Fragmento DK 8 A 2, en Pòrtulas, J., óp cit., p. 494.

[50] En Svenbro, J., óp. cit., p. 101.

[51] Svenbro, J, óp. cit., p. 103.

THÉMATA. Revista de Filosofía, Nº49 enero-junio (2014) pp.: 159-184

doi: 10.12795/themata.2014.i49.09 
respecto, son muy significativos los testimonios que nos indican que Teágenes se dedicó a labores proto-filológicas, preocupándose por el texto, depurando su aspecto unitario y tratando de procurarle la mayor cohesión posible ${ }^{52}$. Teágenes lleva a cabo una crítica del texto en consonancia con la nueva estructuración de la ciudad-estado. El de Regio ya no puede aceptar el carácter multiforme del texto y se esfuerza en confeccionar la reconstrucción más fiel. De hecho, su apología alegórica se basa en la dicción (léxis). Teágenes debe conseguir que Homero siga siendo actual, es decir, ha de hacer de Homero un polítes. En la ciudad del siglo VI, los textos empiezan a reclamar la figura de un autor y, por eso, al de Regio le interesa la existencia de un solo texto y que sea atribuible a un autor concreto, sin ambigüedades ni variaciones incomprensibles. En cualquier caso, la nueva estructura en la que se encuentra, la misma que le permite a Jenófanes elaborar su crítica, le da la posibilidad de encontrar un modo de defender su oficio. El lugar de la verdad ha sido situado en el centro y son los hombres, mediante la deliberación, los que deciden qué es lo más verosímil; la verdad puede ser discutida. La pólis es una realidad social constituida por diferentes posicionamientos y perspectivas que pugnan entre sí. Jenófanes se sitúa en una, pero Teágenes se coloca en otra que, a priori, no será menos válida si los argumentos resultan verosímiles.

La clave de su defensa consiste en hacer del texto homérico algo coherente con la nueva ciudad-estado. Obviamente, lo escrito no puede alterarse, pero sí que puede conjeturarse de Homero una intencionalidad alegórica. Primero se propone esta hipótesis y luego se demuestra que encaja con una determinada lectura del texto. Precisamente, Teágenes dice cuál es la perspectiva desde la que escribió Homero y desde la que debe entenderse su obra. De tal manera, procura que las hazañas de los poemas estén en consonancia con el nuevo marco, extrayendo del propio texto los ejemplos que le convienen y respaldan su teoría.

El rapsoda disloca el texto en dos planos: por una parte, está la lectura aparente o literal; por otra, la lectura profunda o la alegórica. Según su inter-

[52] Schol. Hom. B ad Il. XX 67 (Porfirio I 240, 14 Schrad.) = 8 A 2 DK [trad. de Pòrtulas, J. en su Introducción a la Ilíada, p. 494]: "El discurs sobre el déus tracta sobretot del que és inconvenient $i$ inoportú; perquè afirmen que les contalles sobre els déus són inconvenients. Alguns defensen [les contalles o mites] d'aquestes acusacions basant-se en la dicció (léxis). Consideren que tot hi és dit al legòricament, a propòsit de la natura dels elements (phýsis tôn stoicheiôn), tal com s'esdevé en les lluites entre els déus. Diuen que allò que és sec combat allò que és humit; el que és calent combat el que és fred $i$ el que és lleuger, el que és pesat; $i$, encara, que l'aigua té el poder d'apagar el foc, $i$ el foc, el poder d'eixugar l'aigua. De la mateixa manera, entre tots els elements que formen el tot, hi ha oposició, i cada un es destrueix al seu torn, però el conjunt és etern. [Homer] disposa les batalles anomenant el foc, Apol lo, Hèlios i Hefest; l'aigua, Posidó i Escamandre; la lluna, Àrtemis; l'aire, Hera; etc. Passa igual quan dóna noms de déus a les disposicions de l’ànim: al seny, Atena; a la insensatesa Ares; al desig, Afrodita; al raonament, Hermes; $i$ coses semblants. Aquest mètode per a defensar Homer és molt antic: procedeix de Teàgenes de Règion, el primer que va escriure sobre Homer (hos prôtos égraphe peri homérou), i es fonamenta en la dicció (apò têes léxeos)."

THÉMATA. Revista de Filosofía, Nº49 enero-junio (2014) pp.: 159-184

doi: 10.12795/themata.2014.i49.09 
pretación, aquel que sólo advierte lo que se nos dice literalmente cae en el error de malinterpretar a Homero, pues éste dijo una cosa para expresar o simbolizar otra. Teágenes se vale del perspectivismo, de la posibilidad de establecer una diferenciación de planos dentro de un discurso. Gracias a la interpretación que lleva a cabo consigue hacer de Homero un ciudadano. De este modo,

"un rapsodo di Reggio, Teagene, fu il primo a difendere Omero contro gli attacchi lanciati da Senofane, e la sua difesa gravitò intorno a un metodo di interpretazione allegorica. Abbia impiegato o no il termine hyponoia, Teagene ha dunque certamente applicato una noziene di "profondità" che vi corriesponde. Davanti al testo immutabile, egli ha fatto la scoperta della 'profondità' del discorso omerico, 'profondità' che equivaleva alla sua 'verità' "53.

Este posicionamiento de Teágenes tiene que ponerse en relación con un fenómeno similar en la esfera del arte. En la pintura y la escultura se descubren la perspectiva y la profundidad. A este respecto, Goux ${ }^{54}$ nos habla de un "antropo-centramiento" en Grecia, mediante el que el hombre toma consciencia de sí mismo, de su papel en el conocimiento y en la visión. Goux sostiene que se descubre al sujeto perspectivo en la pintura y en la arquitectura. Empleando su terminología, se pasa de la representación aspectiva, en la que se pinta el objeto de manera fija y siempre igual, a una representación perspectiva, que mediante la autorreflexión se da cuenta de que lo que se ve, en realidad es lo que ve un yo. En la aspectiva el objeto es dibujado en su forma fija y solemne, en la cual el objeto siempre se reconoce con facilidad: es una señal, un signo inmediato. En la perspectiva, en cambio, ya no se pinta el objeto desvinculado del sujeto, sino que se adquiere consciencia de su correlación ${ }^{55}$. La importancia de esto no es menor, pues "el ser humano se reconoce como punto de vista sobre el mundo, como medida central y única de toda cosa" ${ }^{56}$. Svenbro, por su parte, atento a este proceso evolutivo en el ámbito artístico, nos recuerda que la ilusión de la profundidad en el plano pictórico despuntará en la segunda mitad del siglo VI a.C.

En este desarrollo social y cultural que estamos analizando, el concepto de perspectiva, de igual manera que el de méson, se erige en central. $\mathrm{Su}$ incursión no se limita al campo de la literatura, ni al del arte, sino que su repercusión atraviesa todo el proceso de configuración de la nueva ciudad-estado. El objeto deja de ser completamente autónomo para ser un objeto captado desde una perspectiva determinada. El pintor o el escultor deben producir un objeto que pueda reconocerse desde una óptica humana. Por su

[53] Svenbro, J., óp. cit., p. 108.

[54] Goux, J.-J., Edipo filósofo, trad. de L. Pinkler; Buenos Aires, Biblos, 1988.

[55] Es muy elocuente el comentario de Goux sobre la construcción del Partenón en la p. 128 de su Edipo filósofo. El hombre introduce en su arquitectura "deformaciones calculadas", porque se tiene en cuenta el problema de la perspectiva.

[56] Goux, J.-J., óp. cit., p. 134.

THÉMATA. Revista de Filosofía, Nº49 enero-junio (2014) pp.: 159-184

doi: 10.12795/themata.2014.i49.09 
parte, Homero deja de ser un canal de las Musas y es convertido en autor. Teágenes lo rehabilita al mostrarnos cuál es la perspectiva desde la que debe entenderse su obra:

"Ora, "situando" il sistema di Anassimando nel testo omerico, Teaggene ha dunque per così dire fissato il "punto de vista" da cui, secondo lui, l'opera omerica deve essere letta, come se Omero avesse pronunciato un discorso da un "punto di vista" individualizzato ed igualitario" ${ }^{57}$.

Teágenes va contra el punto de vista de Jenófanes proponiendo la perspectiva adecuada para comprender a Homero. El perspectivismo, obviamente, no implica un relativismo: las diferentes posturas pugnan entre sí para persuadirnos de que su punto de vista, y no otro, es el correcto.

El mundo griego está cambiando. Regio y Zancle son ciudades económicamente prósperas y en camino de convertirse en pólis igualitarias ${ }^{58}$. La hegemonía va desligándose paulatinamente de las referencias genealógicas para relacionarse de forma directa con la economía. La capacidad de abstracción cada vez es mayor. La manera de comprender los objetos y relacionarse con ellos está cambiando y lo mismo pasa con las personas. Lentamente comienza a surgir una noción fuerte de individuo. Teágenes ha de defender su trabajo y para eso ha de elaborar una apología de Homero. Pasajes como el de la famosa Theomachía del canto XX de la Ilíada no podían ser aceptados en la moralidad de la pólis. Teágenes, consciente de esto, buscó la manera de conciliarlo con las nuevas exigencias sociales y la encontró en la alegoría: tras lo que se nos explica literalmente, a saber, una batalla entre los dioses, hemos de comprender que se nos habla de una oposición de elementos y disposiciones de conducta. Poseidón debería identificarse con el agua, Apolo con el fuego; Hefesto se corresponde con el fuego, Escamandro con el agua; Hera representa el aire, Artemisa la luna; Atenea corresponde a la razón; Ares y Afrodita, en cambio, apuntan a la locura y el delirio; Hermes simboliza el cálculo y Leto el olvido ${ }^{59}$. Así, Teágenes, entre otras cosas, convierte a Homero en un ciudadano que habla de las tensiones internas de la pólis, o sea, de un conflicto de fuerzas y de perspectivas.

Teágenes, que no puede rechazar ni alterar el texto escrito de los poemas homéricos, ha encontrado en la alegoría el mecanismo capaz de rehabilitar a Homero. El método escogido no es radicalmente opuesto al de Jenófanes, sino que hunde sus raíces en un principio epistemológico idéntico.

[57] Svenbro, J., óp. cit., p. 110.

[58] Decimos "igualitaria", aludiendo a la igualdad de palabra, derechos y deberes entre los dotados de la condición de ciudadano.

[59] Cf. el texto de la nota 52.

THÉMATA. Revista de Filosofía, Nº 49 enero-junio (2014) pp.: 159-184

doi: 10.12795/themata.2014.i49.09 


\begin{abstract}
"Teagene ha scorto il punto debole della ricostruzione senofanea: il suo carattere di operazione proposizionale. In effetti, l'inaccessibilità del tetelesmenon rendeva il dokos una ricostruzione fragile, la cui verifica diretta era privilegio del "soggetto trascendentale", del Dio senofaneo. Rispetto al tetelesmenon, Senofane e Teagene erano entrambi condannati a una stessa impotenza: non lo conoscevano direttamente né l'uno né l'altro. Il dokos dell'uno si opponeva al dokos dell'altro, in un dialogo ad armi pari. Al diritto di parola del filosofo corrispondeva l'uguale diritto del rapsodo, costretto a svincolare il testo omerico dal "barbaro" che l'aveva strutturato. E di questo diritto, il rapsodo fece uso: trattando Omero da "cittadino". O cio "pensieri reconditi" non erano manifesti, l'ha trasformato addirittura in un filosofo dei tratti apertamente milesi. Omero non era affatto il "barbaro" dipinto da Senofane: era un antico filosofo che conosceva la struttura del mondo"60.
\end{abstract}

Es la consecuencia de situar la verdad en el lugar que le corresponde, a saber, el del ámbito humano. Cuando se hace esto, una vez rechazado el derecho a hablar en nombre de una verdad sagrada e incuestionable, se abre la veta para una contraposición de puntos de vista e intereses que difícilmente pueden convergir. El relativismo que ya comienza a gestarse tiene que ver con esta posibilidad que aquí queda abierta. Al reconocer que el conocimiento absoluto sólo le es posible al dios transcendente, el humano queda abocado al mundo de la opinión $(\text { dóxa })^{61}$. Poco a poco, algunos pensadores empiezan a darse cuenta de esto.

El proceso que deseamos esclarecer es harto complejo. Se produce un cambio que permite introducir un corte respecto a la inmediatez y la aspectiva. De forma gradual, comienza a aparecer lo abstracto, lo mediato, el autor y la perspectiva. Con ello nace la posibilidad de hablar de un discurso profundo, pero también la posibilidad de una deliberación asamblearia en la pólis y de otros mecanismos, como el de la ironía. El proceso es rico e intrincado. Obviamente, Jenófanes pudo haberse opuesto a la interpretación alegórica, pero su propia propuesta epistemológica hace muy difícil demostrar la falsedad de una postura alegorizante, ya que saber la intención real de Homero excede los límites del conocimiento humano. Jenófanes, en cierto sentido, queda preso en el mundo de la dóxa. El colofonio y Teágenes luchan con paridad de armas. Según parece, el de Regio le atribuyó a Homero su propia perspectiva, es decir, trató de asignarle a los cantos de Homero una racionalidad contemporánea a su tiempo. Después de todo, tal vez los mitólogos y exégetas no hayan hecho otra cosa a lo largo de la historia.

Sea como fuere, este proceso tan rico cada vez fue impregnando más elementos, con repercusiones decisivas. No parece casual que Parménides o Platón viesen la necesidad de ir un paso más allá de la dóxa para asirse a una

[60] Svenbro, J., óp. cit., p. 117.

[61] Una dóxa que no debe entenderse peyorativamente, sino simplemente como el conocimiento a través de las conjeturas y la falsación. La certeza absoluta parece que nos quede vetada, lo cual no implica que todas las conjeturas sean igual de válidas. En cualquier caso, surge un problema central para la historia de la filosofía.

THÉMATA. Revista de Filosofía, Nº49 enero-junio (2014) pp.: 159-184

doi: 10.12795/themata.2014.i49.09 
verdad no sujeta a las circunstancias humanas. Se requiere un método que permita diferenciar un dókos de otro, pues, de lo contrario, nos vemos abocados al relativismo. Un debate político y epistemológico se ha instaurado en el centro de la pólis y su desarrollo constituye uno de los momentos más apasionantes y cruciales de la historia de la humanidad. Además, en la Grecia Antigua no se había trazado todavía una línea divisoria neta que separase la teoría y la prâxis, por lo que en todos estos debates teóricos había en juego un modus vivendi, una determinada manera de concebir y relacionarse con el mundo. La lucha epistemológica era también una lucha política. Sus repercusiones alcanzan hasta el presente.

\section{«FICCIONES}

"Soy completamente consciente de que no he escrito sino ficciones. No obstante, eso no quiere decir que no sean verdad". [Michel Foucault]

La palabra ficción no quiere decir irreal, falso o sinsentido. Quiere decir que la gente es cultural, que vive en un universo simbólico, que los acontecimientos se interpretan narrándolos.» (Joseba Sarrionandia. La traducción al castellano es mía) 


\section{Referencias bibliográficas:}

\section{Fuentes}

Diógenes Laercio, Vidas y opiniones de los filósofos ilustres, trad. y notas de L. Bredlow. Madrid, Lucina, 2010.

Kirk, Raven y Schofield, Los filósofos presocráticos, trad. de J. García Fernández. Madrid, Gredos, $2^{a}$ reimpresión a la segunda edición, 1999.

Bibliografía

Detienne, M., Los maestros de verdad en la Grecia arcaica, trad. de J. J. Herrera. Madrid. Taurus, 1986.

Dodds, E. R., Los griegos y lo irracional, traducción de M. Araujo. Madrid, Alianza, 1980.

Goux, J.-J., Edipo filósofo, trad. de L. Pinkler. Buenos Aires, Biblos, 1988.

Havelock, E. A., La musa aprende a escribir, trad. de L. Bredlow. Barcelona, Paidós, 1996.

Havelock, E. A., Prefacio a Platón, trad. de R. Buenaventura. Madrid, Antonio Machado Libros, 2002.

Lledó, E., «Introducción a Ion» en Platón: Diálogos I, Madrid: Gredos, 1981, pp. 245-248.

Lord, A. B., "Homer's Originality: Oral Dictated Texts" en Transactions of the American Philological Association 84, pp. 124-134.

Pòrtulas, J., Introducció a la Ilíada, Barcelona. Fundació Bernat Metge, 2009. Svenbro, J., La parola e il marmo, trad. de P. Rosati. Turín, Boringhieri, 1984. Vernant, J.-P., Los orígenes del pensamiento griego, trad. de M. Ayerra. Barcelona, Paidós, 1992. 